Relations industrielles

Industrial Relations

\title{
Comparative Study of the Legislation on Conciliation and Arbitration III - United Kingdom
}

\section{Anonyme}

Volume 6, numéro 3, juin 1951

URI : https://id.erudit.org/iderudit/1023220ar

DOI : https://doi.org/10.7202/1023220ar

Aller au sommaire du numéro

Éditeur(s)

Département des relations industrielles de l’Université Laval

ISSN

0034-379X (imprimé)

1703-8138 (numérique)

Découvrir la revue

Citer cet article

Anonyme (1951). Comparative Study of the Legislation on Conciliation and Arbitration: III - United Kingdom. Relations industrielles / Industrial Relations, 6(3), 72-75. https://doi.org/10.7202/1023220ar

Tous droits réservés @ C Département des relations industrielles de l’Université Laval, 1951
Ce document est protégé par la loi sur le droit d'auteur. L'utilisation des services d'Érudit (y compris la reproduction) est assujettie à sa politique d'utilisation que vous pouvez consulter en ligne.

https://apropos.erudit.org/fr/usagers/politique-dutilisation/ 


\section{Comparative Study of the Legislation on Conciliation and Arbitration *}

\section{III - UNITED KINGDOM}

The system prevailing in the United Kingdom for the settlement of labour disputes is typically British. Both employers' and employees' professional organizations have much developed. Collective bargaining on a wide scale dates further back than in most countries. In all but a few branches of economic activity, there are organizations created as a result of collective agreements for the purpose of settling disputes which may arise in the industries concerned. Due to the advancement of collective bargaining and the strength of professional organizations, the State intervenes only when such an action is expressly desired by the interested parties.

The State intervenes in disputes under the Conciliation Act, 1896, and the Industrial Courts Act, 1919. After a study of the technicalities of the State intervention under the above mentioned acts, we shall pay some attention to the main provisions of the Conditions of Employment and National Arbitration Order, 1940, such provisions having been maintained by the Act, Wages Council 1945 , whose powers have been increased by the Act of December 16, 1948.

The usual methods employed by the Ministry of Labour and the $\mathrm{Na}$ tional Service may be brought down to three: A) Committees of Investigation and Courts of Inquiry; B) Conciliation; C) Arbitration. These methods are applied by virtue of the Acts of 1896 and of 1919.

* Third study of a series prepared by a Professor in the Industrial Relations Department of Laval University.

\section{A - Courts of Inquiry}

Under the Industrial Courts Act, 1919 , the Minister has power to inquire into the causes and the circumstances of any trade dispute and, if he thinks fit, to appoint a Court of Inquiry to inquire into the matter. The consent of the parties to the appointment of a Court is not required. ${ }^{1}$ A Court of Inquiry consists of a Chairman and of one or more persons selected and appointed by the Minister. The Chairman is always an independent person, but the other Members of the Court may consist of persons representing employers and workers outside the industry concerned. A court may be authorized to require persons to furnish information or to appear before the Court. Courts of Inquiry are primarily a mean of informing Parliament and public opinion of the facts and underlying causes of a dispute. Also, a Court may make recommendations upon which a reasonable settlement of the dispute can be based but neither party to the dispute is bound to put into operation any recommendations which a Court may make. ${ }^{2}$ The Act requires that any report of a Court shall be laid as soon as may be before Parliament. In practice, the Minister resorts to this method only for matters of major importance affecting wider interests than those of the immediate parties to the dispute.

(1) Industrial Relations Handbook, p. 122, London - His Majesty's Stationery Office, 1944.

(2) Industrial Relations. Report VIII (1), p. 106, Thirty-first Session, San Francisco, 1948, International Labour Office. 


\section{B - Committees of Investigation}

The Minister may, in pursuance of the Conciliation Act, 1896, appoint a Committee of Investigation to inquire into the causes and circumstances of a dispute. Such a Committee may be constituted in the same way as a Court of Inquiry. A Committee of Investigation has not the same powers as a Court of Inquiry to call for information but by its less formal nature a Committtee may adopt a more flexible procedure and may be able to formulate proposals in the course of its inquiry which form the basis of an agreed settlement of the dispute. The Committee is under no obligation to lay the report before Parliament.

\section{C - Conciliation}

The Act of 1896 makes it possible for the Department of Labour to take such steps as may seem expedient to conciliate the parties to a dispute. Although the Minister may take measures in his own initiative, he does not do so habitually unless the ordinary negotiating machinery has been fully utilized. ${ }^{3}$ In pursuance of the Act, the Minister may take steps to induce the parties to meet together and reach a settlement under the chairmanship of a person designated by the parties themselves or appointed by the Minister, or under the chairmanship of an authority accepted by both parties. Besides, upon request from either party, the Minister, after considering the various means of conciliation existing in the industry or locality as well as the circumstances of the dispute, may appoint a person as conciliator or many persons to constitute a board of conciliation. There is no direct intervention by the Minister of Labour unless the parties have

(3) Idem, p. 97. exhausted all available means of conciliation.

\section{D - Arbitration}

The forms of arbitration are determined by the Industrial Courts Act, 1919, and the Conciliation Act, 1896. Let us say that the Act of 1919 deals more deeply with arbitration matters than that of 1896. When arbitration is decided upon, the dispute may be submitted: 1) to an arbitrator; 2) to a Joint Board of Arbitration; 3) to the Industrial Court. In all cases, the arbitration machinery cannot operate without the consent of the parties. Furthermore, before resorting to the arbitration procedure, the Minister of Labour shall make sure that all conciliation or arbitration procedures provided for the parties themselves have been fully utilized without satisfactory results. Arbitral awards are neither mandatory nor binding upon the parties. However, as the arbitration procedure has been requested by both parties, the awards are generally accepted. *

\section{1) Appointment of an arbitrator}

As above mentioned, the Act stipulates that a dispute may be submitted to a single arbitrator. This arbitrator may secure the assistance of assessors but the latter are not formally associated with the award in any way and the extent of their activities is a matter for the arbitrator to decide. ${ }^{5}$

\section{2) Ad Hoc Board of Arbitration}

Should the parties so desire, the dispute is submitted to a temporary Board of Arbitration composed of an equal number of employers' and of

(4) Industrial Relations Handbook, p. 119.

(5) Revue française du Travail. - Le règlement des conflits collectifs de travail en France et à l'étranger, par Renée Petit, maijuin 1949. 
workers' representatives, under the chairmanship of a person nominated by the Minister of Labour. Such boards are constituted for each dispute. In principle, the powers of a board cease with the issue of the arbitral award. Consequently, all questions of interpretation cannot be submitted directly to the original board by the parties. They are referred to the Minister of Labour who usually requires the consent of both sides before submission to the original Board. The same applies in the case of requests for interpretation of an award rendered by a single arbitrator.

\section{3) Industrial Court}

The Industrial Court is a permanent and independent body, and its activities are subject to no official control. It is composed of members appointed by the Minister of Labour, some of whom are independent persons while others represent employers or employees; furthermore, there shall be one or more female members. The president of the Court has the casting vote. When a dispute is submitted to the Court, it consists of such persons as are designated by the President. "As a rule, each case is examined by a Division of the Court consisting of the President himself or of a President elected among the independent members and of other members representing either the employers or the workers" "6. The Court is generally composed of three members. The president may secure the assistance of one or more assessors.

Three conditions shall be complied with before a dispute can be submitted to the Industrial Court: " 1 ) report addressed to the Minister by one of the parties involved to inform

(6) Conciliation and Arbitration of Labour Disputes, p. 184 . - International Labour Office, Etudes et Documents, Série A (Vie sociale), No 34, Genève, 1933. the Minister of the existence of a dispute; 2) proof deemed sufficient by the Minister that there exists no agreement through which the dispute may or might be settled under an arbitration procedure, or that such procedure has been resorted to without results; 3) written consent of both parties served with whom it may concern " $"$.

The decisions of the Court are not enforceable but when they are accepted they form terms or conditions of the contract of employment. When the members of the Court are unable. to agree as to an award, the matter is decided by the President acting with the full powers of an Umpire. The parties may be represented by Counsel or Solicitors, with the consent of the Court, but this action is generally not encouraged by the Court. Should either party decide to be represented by Counsel, the other party is so informed in advance.

As for questions pertaining to the interpretation of an Award of the Court, the Minister of Labour or one of the interested parties may ask the Court for a decision on the matter. Where necessary the Court arranges for a further hearing before giving such a decision.

Let us add, finally, that the Court may be asked to give advice to the Minister of Labour on any question connected with a trade dispute or any other matter which, in the opinion of the Minister, ought to be referred to the Court.

\section{E - National Arbitration Tribunal}

The National Arbitration Tribunal was established under the Conditions of Employment and National Arbitration Order, 1940, some provisions of which, embodied in the Wages Councils Act, 1945, shall remain in force until December 31, 1950, unless

(7) Idem, p. 184.

The Industrial Relations Review 
this period of enforcement be extended by Parliament. We have, here, a wartime legislation tending, for a limited period, to compulsory arbitration of disputes. The parties to the dispute shall report the dispute in writing to the Minister of Labour. If in the trade or industry concerned there is collective joint machinery which is suitable for settling the dispute, the Minister refers the dispute to that machinery. If there is failure to reach a settlement or a settlement appears to the Minister to be unduly delayed, he can refer the dispute to the National Arbitration Tribunal. In cases in which there is no suitable joint machinery in existence and there is failure to settle the dispute by conciliation, the Minister may likewise refer the dispute to the National Arbitration Tribunal. ${ }^{8}$ The National Arbitration Tribunal consists of five members, three being Appointed Members, one of whom is Chairman, together with two other members, one of whom represents workers and the other employers. The Tribunal is constituted for each dispute and its decisions are binding upon the parties.

\section{F - Nationalized Industries}

The Gas Act, 1948, like the Transport and Electricity Acts of 1947, provide for the establisment of joint machinery for the purpose of fixing wages and other conditions of employment. ${ }^{9}$ Under a collective agreement concluded on March 31, 1938, between the British Electricity $\mathbf{A u}$ thority and the trade unions, a special procedure is provided for the settlement of labour disputes which may arise. As a last resort, the dispute is referred to the Industrial Court or to any other agreed tribunal for arbitration. The award made is binding upon the boards, the unions and the members of the unions. ${ }^{10}$

\section{IV - FREE STATE OF IRELAND}

The settlement of labour disputes is regulated by the Industrial Relations Act, August 27, 1946, which deals mostly with the Labour Court, collective agreements and trade disputes. $^{1}$

\section{A - Labour Court}

The Court shall consist of a chairman appointed by the Minister and four ordinary members of whom two shall be workers' members and two shall be employers' members. The Minister shall designate an organi-

(8) Le règlement des conflits collectifs de travail en France et à l'étranger, Renée Petit, p. 268.

(1) An Act dated 27th August 1946, respecting labour relations, Legislative Series, 1946, Ireland 1, International Labour Office. zation representative of trade unions to nominate persons for appointment. The two members of the Court to represent employers are designated in the same way. The Minister appoints the persons so nominated.

If, in the case of workers, more than one organization representative of trade unions is in being, and the Minister is of the opinion that it is undesirable that the appointment should be made as indicated in the foregoing paragraph, he may, by regulations, declare that the appointment be made as follows:

i) he invites trade unions of workers and organizations representative of trade unions of workers to

(9) Industrial Relations, Report V (Supplement) p. 7, Thirty-second Session, Geneva, 1949, International Labour Office.

(10) Idem, p. 32. 